\title{
Adsorption of Ions onto Treated Natural Zeolite
}

\author{
Cristiane da Rosa Oliveira, Jorge Rubio* \\ Programa de Pós Graduação em Engenharia de Materiais, \\ Laboratório de Tecnologia Mineral e Ambiental - LTM, \\ Departamento de Engenharia de Minas, Universidade Federal do Rio Grande do Sul-UFRGS, \\ Av. Bento Gonçalves, 9500/75, 91501-970 Porto Alegre - RS, Brazil
}

Received: March 27, 2007; Revised: October 9, 2007

\begin{abstract}
This work presents studies of modification of a natural zeolite by activation with $\mathrm{Na}^{+}$cations and functionalisation with $\mathrm{Ba}^{+2}$ and/or $\mathrm{Cu}^{2+}$ ions (FZ). The zeolite was characterized, modified and applied in adsorption studies of sulphate and isopropilxanthate ions as flocculated and powdered forms. The reuse of $\mathrm{SO}_{4} \mathrm{Ba}-\mathrm{FZ}$ was investigated by adsorption-removal of either $\mathrm{Ba}^{2+}$ or sulphate ions in stages. Equilibrium data showed that the FZ, flocculated or as powder, provide considerable removal of sulphate ions $\left(\mathrm{q}_{\mathrm{mLangmuir}}: 1.15\right.$ and 1.35 meq. $\mathrm{g}^{-1}$, respectively) and isopropilxanthate $\left(\mathrm{q}_{\text {mLangmuir }}: 0.35\right.$ and $0.93 \mathrm{meq} \cdot \mathrm{g}^{-1}$, respectively). The reuse of the $\mathrm{SO}_{4}-\mathrm{FZ}$, either powdered or flocculated also uptake significant amount of $\mathrm{Ba}^{2+}$ or sulphate ions $\left(\mathrm{q}_{\text {mLangmuir }}: 1.15\right.$ meq. $\left.\mathrm{g}^{-1}\right)$, providing a new alternative for the exhausted adsorbent. Thus the activated and functionalised zeolites create new options on the materials engineering area with applications in environmental applied adsorption processes.
\end{abstract}

Keywords: natural zeolites, modified materials, adsorption

\section{Introduction}

Natural zeolites are hydrated aluminosilicates based on an infinite three-dimensional structure of tetrahedrons as $\mathrm{TO}_{4}(\mathrm{~T}=\mathrm{Si}, \mathrm{Al}, \mathrm{B}, \mathrm{Ge}$, $\mathrm{Fe}, \mathrm{P}, \mathrm{Co}$ ) joined by oxygen atoms ${ }^{4,14}$. Zeolites have in its internal structure channels and cavities interconnected of molecular dimensions where compensation cations allowing the ion exchange ${ }^{15,16}$ exist.

Zeolite materials allow an introduction of new functional groups through several processes of modification, improving substantially its activity and selectivity on the removal several substances ${ }^{3,7,12,13,17}$. Many authors show the use of modified natural zeolite on environmental applications, mainly anions uptake from effluents by adsorption processes $^{10,11,20,21}$.

The present work describes studies of characterization, modification (treatment) and application of a natural zeolite from Chile. The zeolites treatment (activation and functionalisation) was validated through of the application of the treated material as powdered, flocs and saturated forms in adsorption processes.

\section{Materials and methods}

\subsection{Materials and reagents}

A natural zeolite (NZ) from Minera Formas ${ }^{\mathrm{TM}}$ (Chile) was used as adsorbent. Reagents of analytical purity $\mathrm{NaCl}, \mathrm{BaCl}_{2} \cdot 2 \mathrm{H}_{2} \mathrm{O}$, $\mathrm{Cu}\left(\mathrm{NO}_{3}\right)_{2} \cdot 3 \mathrm{H}_{2} \mathrm{O}, \mathrm{Na}_{2} \mathrm{SO}_{4}$ and $\left(\left(\mathrm{CH}_{3}\right)_{2} \mathrm{CHOCS}_{2} \mathrm{Na}\right)$ were used on the activation, functionalisation and adsorption studies, respectively.

Studies of cationic exchange capacity of the zeolite used the reagent of analytical purity $\left(\mathrm{NH}_{4}\right)_{2} \mathrm{SO}_{4}$.) Aqueous solutions of methylene blue $\left(\mathrm{C}_{16} \mathrm{H}_{18} \mathrm{~N}_{3} \mathrm{SCI} .3 \mathrm{H}_{2} \mathrm{O}\right)$ were used on the determination of the specific surface area of the zeolite, by adsorption.

The $\mathrm{pH}$ adjustment was done using $\mathrm{HNO}_{3}$ and $\mathrm{KOH}$ solutions.

The polymers NALCO 8589 (cationic), MAFLOC 460 (cationic), MAFLOC 2880 (anionic) and QEMIFLOC AH1020 PWG (nonionic) were used on the flocculation studies.

\subsection{Chemical analysis}

Isopropilxanthate ions concentration was measured using the spectrophotometric method of analyse. This method consisted in direct measurement of the light absorbance, at $301 \mathrm{~nm}$, of the aqueous solutions and results were compared with a calibration ${ }^{22}$.

Sulphate ions and ammonia nitrogen concentrations were measured using the methods of analyze described in the Standard Methods for the Examination of Water and Wastewate ${ }^{1}$.

The concentration of methylene blue was determined by spectrophotometry ${ }^{19}$.

\subsection{Chemical, physical and mineralogical characterization}

The particle size distribution of powdered zeolite was determined using laser diffraction equipment (CILAS $\left.{ }^{\mathrm{TM}} 1064\right)$.

The specific surface area of the zeolite was evaluated by methylene blue adsorption method. Thus, aqueous solutions $(50 \mathrm{~mL})$ of methylene blue (100 mg. $\left.\mathrm{L}^{-1}\right)$ were mixed for 1 hour at room temperature in the presence of different zeolite concentrations. The suspensions were stood up for 23 hours and resulting supernatants were centrifuged and analyzed (methylene blue residual concentration). The specific surface area, evaluated by the Langmuir using $1.08 \mathrm{~nm}^{2}$ molecule ${ }^{-1}$ for the cross-sectional area ${ }^{16,19}$ gave an experimental error of $\pm 4.2 \mathrm{~m}^{2} . \mathrm{g}^{-1}$.

The cation-exchange capacity of the zeolites was determined by activation of material with an aqueous solution of $\mathrm{NaCl}$. A know quantity of the natural zeolite $(5 \mathrm{~g})$ was mixed with $50 \mathrm{~mL}$ of a $\mathrm{NaCl}$ $1 \mathrm{M}$ solution in a glass flask using a Wagner shaker (Marconi ${ }^{\mathrm{TM}}$ ) during 24 hours at room temperature. The resultant suspension was filtrated and washed three times with $300 \mathrm{~mL}$ deionised water. The wet activated material was dried at $100{ }^{\circ} \mathrm{C}$ for 24 hours and used in adsorption studies for ammonia uptake. Thus, a known quantity of activated zeolite $(0.25 \mathrm{~g})$ was mixed with $0.1 \mathrm{~L}$ of a solution $(100 \mathrm{mg}$ $\left.\mathrm{NH}_{3}-\mathrm{NL}^{-1}\right)$ in an agitated glass flasks for 2 hours. Data were calculated considering the number of equivalent-gram of ammonium cations (18 $\mathrm{mg} \mathrm{NH}_{3}-\mathrm{N} \mathrm{meq}^{-1} \mathrm{NH}_{4}^{+}$) adsorbed ${ }^{16}$ with an experimental error of \pm 0.02 meq $\mathrm{NH}_{4}^{+} \mathrm{g}^{-1}$. 
The specific mass was measured by picnometry. Here, an amount of material was inserted in a picnometer with water at $4{ }^{\circ} \mathrm{C}$ until fulfilment of the volume of the recipient and measured the different masses. Thus, using the known masses of water, sample and recipient, results obtained allowed to determine the specific mass of the zeolite expressed in terms of g. $\mathrm{cm}^{-3}$ with an experimental error of $\pm 0.007{\mathrm{~g} . \mathrm{cm}^{-3}}^{-3}$. The porosity was determined by the difference between the unit and the relation bulk specific mass and specific mass of the particle ${ }^{5}$ with an experimental error of \pm 0.002 .

Moisture of the zeolite was evaluated by gravimetric means. A sample $(1 \mathrm{~g})$ of the material was dried at $100{ }^{\circ} \mathrm{C}$ for 24 hours, cooled in a desiccator and its mass was monitored in an analytical balance (precision $\pm 0.1 \mathrm{mg}$ ) by several times. The difference between the dried mass value and the equilibrium mass value was used to evaluate the moisture content (Experimental error: $\pm 0.01 \%$ ).

Scanning electron microscopy (SEM-Philips ${ }^{\mathrm{TM}}$ XL20) was used for photomicrographs as well as to analyze of zeolite composition (Energy Dispersion X ray, EDX). The sample was initially placed in a vacuum chamber for coating with a thin layer (few nanometres) of gold $(\mathrm{Au})$.

Mineralogical structure of the zeolite was determined by Energy Dispersion X ray (EDX) using diffraction equipment (MPD-Philips ${ }^{\mathrm{TM}}$ ) indicating the main mineral phases of its crystalline structure.

Zeta potential measurements for the natural (NZ), activated (Na-Z) and functionalised zeolite (Ba-FZ or $\mathrm{Cu}-\mathrm{FZ}$ ), as a function of medium $\mathrm{pH}$, were determined using a Zeta Plus ${ }^{\mathrm{TM}}$ equipment (Broohaven Instruments). Suspensions $\left(0.01 \%{\left.\mathrm{v} . \mathrm{v}^{-1}\right)}\right.$ of the zeolite, previously sieved below $37 \mu \mathrm{m}\left(400\right.$ Mesh Tyler $\left.{ }^{\mathrm{TM}}\right)$, in a $10^{-3}$ mol. $\mathrm{L}^{-1}$ solution of $\mathrm{KNO}_{3}$ were used and the medium $\mathrm{pH}$ was controlled with the addition of $\mathrm{HNO}_{3}(\mathrm{pH}<7)$ and $\mathrm{KOH}(\mathrm{pH}>7)$, separately.

\subsection{Modification of zeolite}

Modification was performed by stages of activation with sodium ions and functionalisation with barium and copper ions. Activation of the zeolite was carried out by contact of the powdered material with an aqueous solution of sodium chloride. A known quantity of the adsorbent $(5 \mathrm{~g})$ was mixed with $0.05 \mathrm{~L}$ of $\mathrm{NaCl} 1 \mathrm{M}$ solution for 24 hours, at room temperature, and the suspension was agitated (at $50 \mathrm{rpm}$ ) in glass flasks using a Wagner shaker. Then, the suspension was filtered and the material washed with $0.3 \mathrm{~L}$ deionised water. The wet activated material was dried in a $100{ }^{\circ} \mathrm{C}$ for 24 hours and used in the functionalisation stage.

The functionalisation with barium and copper ions of the activated zeolite was performed contacting the powdered material samples with aqueous solutions of barium chloride and copper nitrate, respectively. Thus, $5 \mathrm{~g}$ were contacted with $0.05 \mathrm{~L}$ of the solutions $\left(1.08 \mathrm{meq} \mathrm{Ba.g}{ }^{-1}\right.$


sion agitated, at $50 \mathrm{rpm}$, in glass flasks in the same Wagner shaker. Then, the suspension was filtered, washed with $0.3 \mathrm{~L}$ deionised water, dried at $100{ }^{\circ} \mathrm{C}$ for 24 hours and used in the adsorption studies.

\subsection{Flocculation studies}

Flocculation studies of the modified zeolite were performed using Jar Test ${ }^{\mathrm{TM}}$ method. Thus, $1 \mathrm{~g}$ of the material was mixed with $0.5 \mathrm{~L}$ of deionised water. Thus, the suspensions were stirred for 15 minutes to achieve the adsorption equilibrium. Then, commercial synthetic polymers solutions were added to the suspensions under high shear with agitation (4 minutes at $120 \mathrm{rpm}$ ) followed by slow agitation (6 minutes at $50 \mathrm{rpm}$ ) for the flocs growth and finally, 5 minutes for the flocs settling. Then, the supernatant turbidity was measured. Best flocculant dosages were determined in duplicate tests. The experimental error was about 2.2 NTU and 0.8 NTU for the turbidity measurements using $\mathrm{Ba}-\mathrm{FZ}$ and $\mathrm{Cu}-\mathrm{FZ}$, respectively.

\subsection{Adsorption studies using functionalised zeolite}

Adsorption studies of sulphate ions onto Ba-FZ were carried out in glass flasks containing $1 \mathrm{~g}$ of the adsorbent material and $0.1 \mathrm{~L}$ of synthetic solution with different concentrations of the solute. The studies of adsorption isopropilxanthate ions were performed using $0.1 \mathrm{~L}$ of aqueous solution of isopropilxanthate ions $\left(60 \mathrm{mg} . \mathrm{L}^{-1}\right)$ and different concentrations of $\mathrm{Cu}-\mathrm{FZ}$ in $\mathrm{pH}$ 8.0. The systems were agitated $(50 \mathrm{rpm})$ in a Wagner shaker during 2 hours (value taken from adsorption kinetic studies which followed the same experimental procedure described above and varying the contact time). After adsorption completion, the suspensions were filtrated and analyzed $(\mathrm{pH}$, temperature and ions concentration). Adsorption studies onto flocculated material used constant mass and a previous stage of flocculation.

The ions uptake (q), expressed as ions removal per unit mass of adsorbent material $\left(\mathrm{mg} \cdot \mathrm{g}^{-1}\right)$, was calculated from the experimental data $\left(\mathrm{C}_{\mathrm{o}}, \mathrm{V}, \mathrm{W}\right.$ and $\left.\mathrm{C}_{\mathrm{f}}\right)$ in each sample according to Equation 1.

$$
q=\frac{V\left(C_{o}-C_{f}\right)}{m}
$$

where, $\mathrm{V}$ is the volume of the solute aqueous solution, Co corresponds to the initial solute concentration, $\mathrm{Cf}$, the final solute concentration and $\mathrm{m}$ is the mass of adsorbent material ${ }^{2}$

The equilibrium data (isotherm) were fitted by Langmuir and Freundlich models by non-linear regression using the Origin 4.1 software. Therefore, the experimental data fitted very well to Langmuir model (Freundlich model fitting was not showed here).

\subsection{Reuse of the saturated zeolite}

Reuse studies of saturated zeolite with sulphate ions $\left(\mathrm{SO}_{4} \mathrm{Ba}-\mathrm{Z}\right)$ were performed for the sequential uptakes of barium and sulphate ions. Powdered functionalised material (Ba-FZ) was saturated with sulphate ions in the adsorption studies using known concentration of an aqueous solution of sulphate ions (1800 mg. $\left.\mathrm{L}^{-1}\right)$. The dried saturated material $\left(\mathrm{SO}_{4} \mathrm{Ba}-\mathrm{Z}\right)$ was reused through contact of $1 \mathrm{~g}$ of the adsorbent and a $0.05 \mathrm{~L}$ of barium chloride aqueous solution for 2 hours. The wet material was washed with $0.3 \mathrm{~L}$ deionised water, dried at $100{ }^{\circ} \mathrm{C}$ for 24 hours and used again on batch adsorption experiments of sulphate ions. In the case of the saturated flocculated materials reuse, the studies used the wet flocs from the washing process with deionised water. Figure 1 illustrates the different stages of the reuse of saturated flocculated materials. The sulphate ions uptake (q) was calculated as described in the adsorption studies.

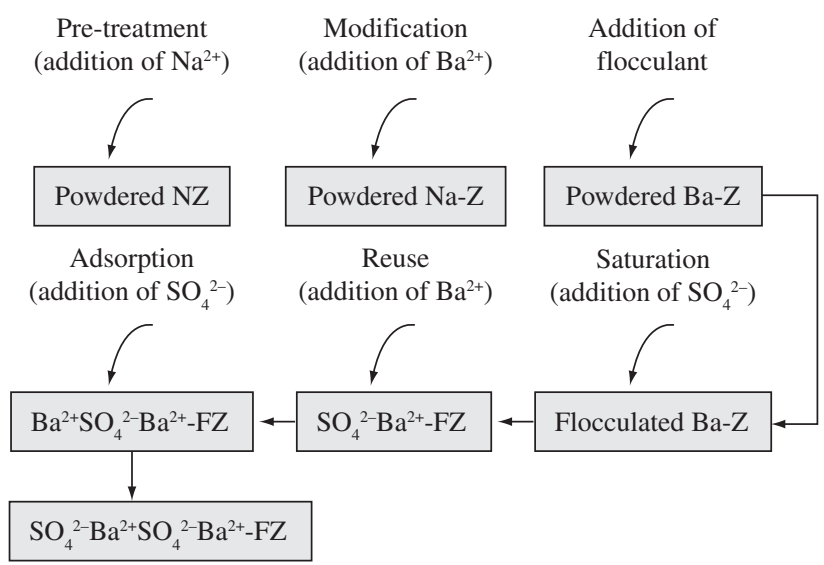

Figure 1. Staged reuse studies of saturated flocculated zeolites as "adsorbents". (NZ: natural zeolite; Na-Z: pre-treated zeolite; Ba-Z: modified zeolite with barium ions; and FZ: flocculated zeolite). 


\section{Results and Discussions}

\subsection{Chemical, physical and mineralogical characterization}

The particle size distribution of the zeolite, obtained by laser diffraction method, is shown in Figure 2.

The size distribution analyze showed $100 \%$ of the particles have minor size of $105 \mu \mathrm{m}$ and the mean particle diameter (volumetric) obtained was about $25 \mu \mathrm{m}$ (Experimental error: $\pm 0.01 \mu \mathrm{m})$.

Additional results obtained on the characterization of the zeolite are shown in the Table 1.

Photomicrographs of the zeolite sample obtained by SEM, are shown in Figures 3 and 4

The qualitative composition analysis (EDX) obtained for the zeolite shown in Figure 4 can be seen in Figure 5 and the mineralogical composition is represented in the Figure 6 and described in the Table 2.

The Figure 5 shows the peaks of the main chemical elements $(\mathrm{O}$, $\mathrm{Na}, \mathrm{Al}, \mathrm{Si}, \mathrm{P}, \mathrm{K}$ and $\mathrm{Fe}$ ) that are present in the structure of this natural zeolite, in agreement with the chemical composition (Table 2).

Zeta potential measurements obtained for the natural zeolite (NZ), activated zeolite (Na-Z) and functionalised zeolite (Ba-FZ and $\mathrm{Cu}-$ FZ), as a function of medium $\mathrm{pH}$ are shown in the Figures 7 and 8.

Figures 7 and 8 show that natural zeolite (NZ) surface groups are electronegative in all $\mathrm{pH}$ range studied. Yet, the samples of $\mathrm{Cu}-\mathrm{FZ}$ and $\mathrm{Ba}-\mathrm{FZ}$ kept the same charge density electronegative compared with the Na-Z indicating an adsorption mechanism during the stage of functionalised mainly by ionic exchange.

\subsection{Flocculation studies}

Results obtained on the flocculation studies of Ba-FZ and Cu-FZ, both in water, showed the cationic polymer Nalco 8589 was the best flocculant for these systems. Data of the investigations of optimal dosage as a function of the residual turbidity are show in the Table 3.

Table 3 shows that the concentrations of $1 \mathrm{mg} . \mathrm{L}^{-1}\left(0.5 \mathrm{mg} \cdot \mathrm{g}^{-1}\right)$ and $3 \mathrm{mg} \cdot \mathrm{L}^{-1}\left(1.5 \mathrm{mg} \cdot \mathrm{g}^{-1}\right)$ for the systems $\left(\mathrm{Ba}-\mathrm{FZ}+\mathrm{H}_{2} \mathrm{O}\right)$ and $(\mathrm{Cu}-\mathrm{FZ}$

Table 1. Characterization data of natural zeolite.

\begin{tabular}{lc}
\hline Specific surface area & $80 \mathrm{~m}^{2} \cdot \mathrm{g}^{-1}$ \\
\hline Cation-exchange capacity & $1.08 \mathrm{meq} \mathrm{NH}{ }_{4}^{+} \mathrm{g}^{-1}$ \\
Specific mass & $2.2 \mathrm{~g} \cdot \mathrm{cm}^{-3}$ \\
Porosity & 0.89 \\
Moisture & $2.5 \%$ \\
\hline
\end{tabular}

Table 2. Mineralogical composition of the zeolite and respective peaks.

\begin{tabular}{|c|c|c|c|}
\hline Phases & Peaks & Phases & Peaks \\
\hline Clinoptilolite & $2,9,10,11,15$ & Quartz & $\begin{array}{l}8,13,18,21,22 \\
23,24,25\end{array}$ \\
\hline Gismondine & 17,21 & Mordenite & $\begin{array}{l}1,12,20,9,5,19, \\
3,4\end{array}$ \\
\hline Heulandite & 7,16 & Offretite & 6 \\
\hline
\end{tabular}

Table 3. Influence of the Nalco 8589 as function of the residual turbidity of the supernatant for the systems $\left(\mathrm{Ba}-\mathrm{FZ}+\mathrm{H}_{2} \mathrm{O}\right)$ and $\left(\mathrm{Cu}-\mathrm{FZ}+\mathrm{H}_{2} \mathrm{O}\right)$.

\begin{tabular}{lccccc}
\hline [Nalco 8589], mg.L - $^{-1}$ & 0.5 & 1.0 & 3.0 & 5.0 & 10.0 \\
\hline Turbidity $\left(\mathrm{Ba}-\mathrm{FZ}+\mathrm{H}_{2} \mathrm{O}\right), \mathrm{NTU}$ & 15.5 & 16.5 & 36.5 & 59.7 & 83.2 \\
Turbidity $\left(\mathrm{Cu}-\mathrm{FZ}+\mathrm{H}_{2} \mathrm{O}\right), \mathrm{NTU}$ & 8.2 & 7.3 & 21.7 & 40.2 & 56.2 \\
\hline
\end{tabular}

Temperature: $25^{\circ} \mathrm{C}$; Inicial turbidity: 352 NTU: [Ba-FZ]: 2 g.L. ${ }^{-1}$; [Cu-FZ]: 2 g.L $\mathrm{L}^{-1}$; Experimental error: (Ba-FZ): $\pm 2,2$ NTU.; (Cu-FZ) $\pm 0,8$ NTU.
$+\mathrm{H}_{2} \mathrm{O}$ ), respectively, provided low turbidity of the supernatant and satisfactory formation of flocs.

\subsection{Adsorption studies using functionalised zeolite}

Kinetic adsorption studies showed rate constants values for sulphate and isopropilxanthate of 0.24 and 0.46 minutes $^{-1}$ respectively. These values followed a first-order reaction kinetic model and reached the adsorption equilibrium in about 20 and 10 minutes (each case), indicating the existence of the adsorption equilibrium.

Figures 9 and 10 show equilibrium data (isotherms) for sulphate ions adsorption onto functionalised zeolite with barium ions as powdered and flocculated forms, respectively.

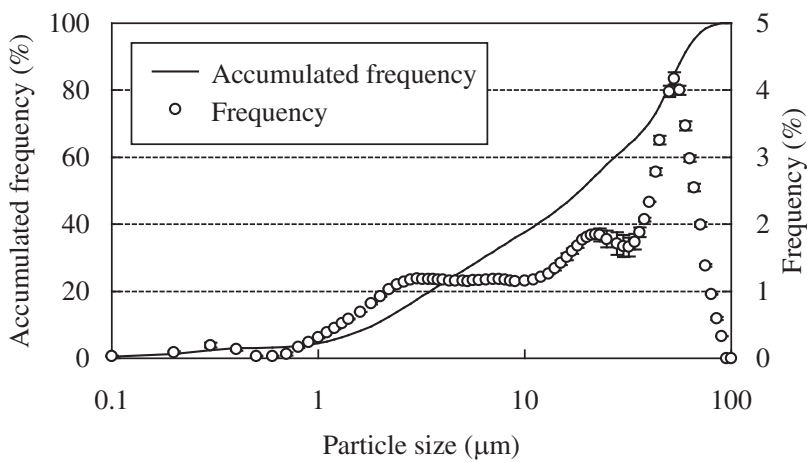

Figure 2. Particle size distribution of the zeolite. Erro exp.: $\pm 0.012 \%$.

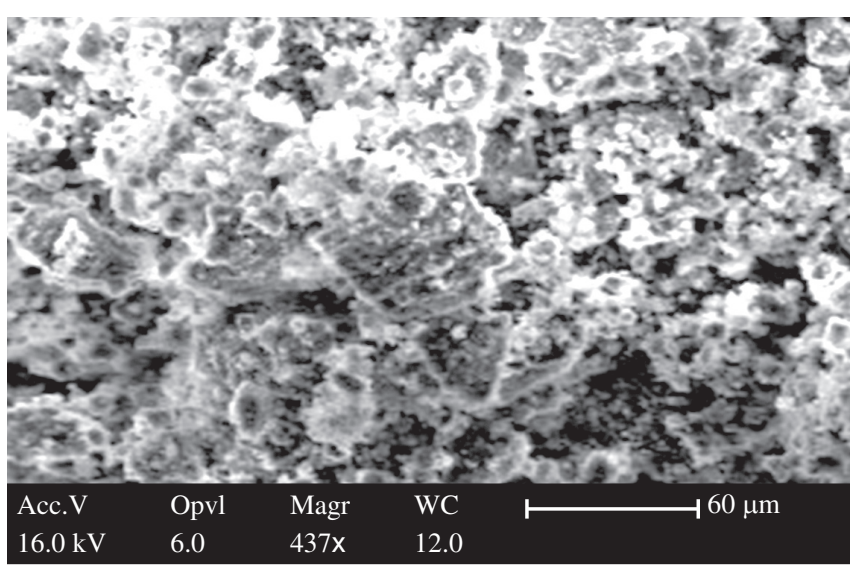

Figure 3. Image of zeolite particles obtained by scanning electron microscopy. Bar length is $50 \mu \mathrm{m}$. and the magnification $487 \mathrm{x}$.

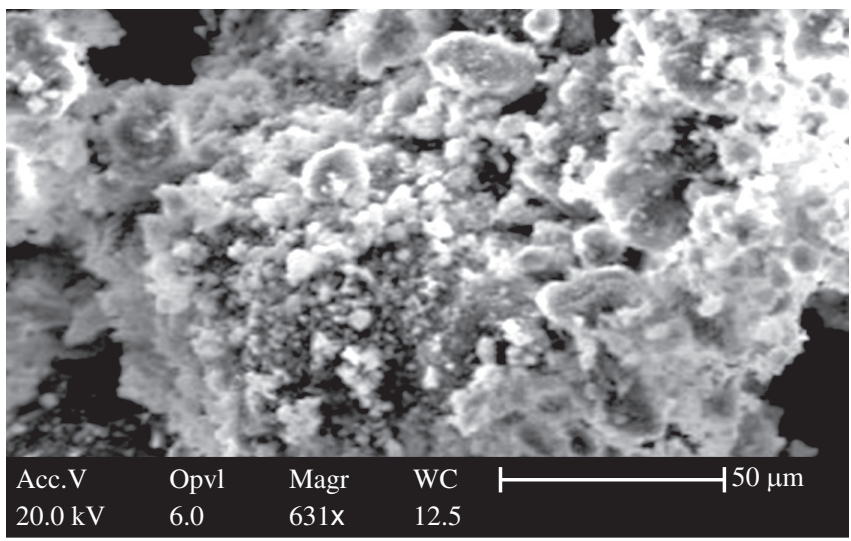

Figure 4. Image of zeolite particles obtained by scanning electron microscopy. Bar length is $50 \mu \mathrm{m}$. and the magnification 631x. 


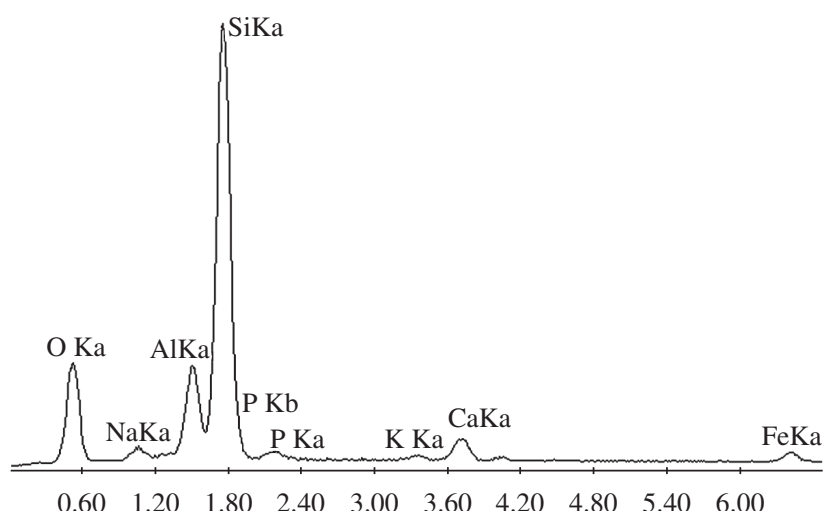

Figure 5. Scanning electron spectral analyses of a zeolite.

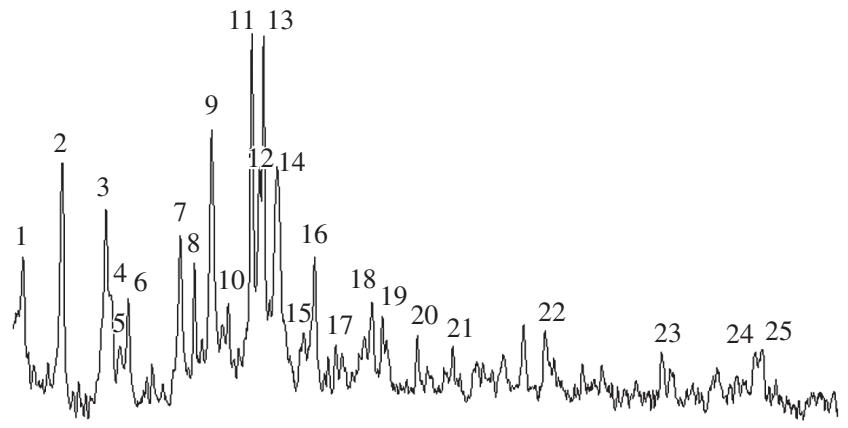

Figure 6. Mineralogical composition of the zeolite obtained by EDX.

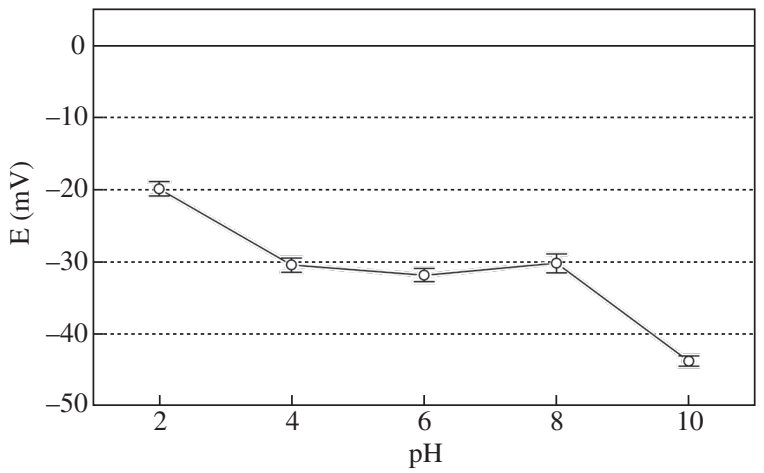

Figure 7. Zeta potential of the natural zeolite. Experimental error: $\pm 0.7 \mathrm{mV}$.

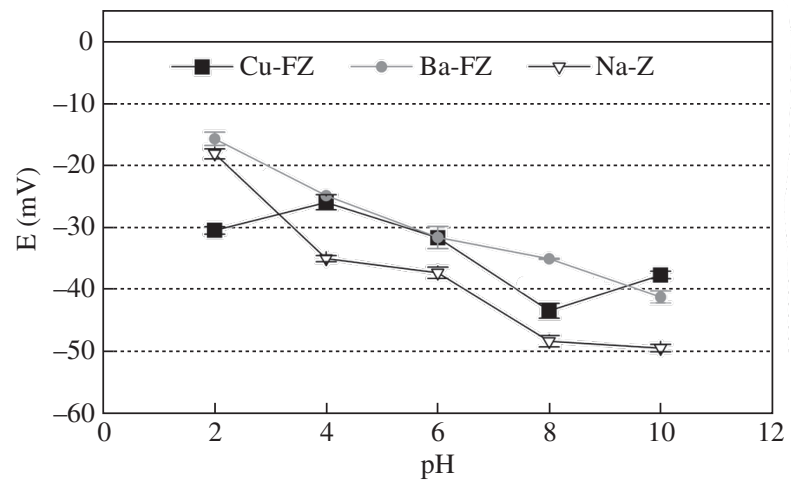

Figure 8. Zeta potential of the activated zeolite (Na-Z), functionalised zeolite (FZ) with barium ions (Ba-FZ) and cooper ions ( $\mathrm{Cu}-\mathrm{FZ})$. Experimental error: $\mathrm{Na}-\mathrm{Z}( \pm 0.7 \mathrm{mV}), \mathrm{Ba}-\mathrm{FZ}( \pm 0.8 \mathrm{mV}), \mathrm{Cu}-\mathrm{FZ}( \pm 1.3 \mathrm{mV})$.
The data (Figures 9 and 10) shows value of the Langmuir parameter $\mathrm{q}_{\mathrm{m}}$ of 1.35 meq. $\mathrm{g}^{-1}$ for the powdered material and $1.15 \mathrm{meq} . \mathrm{g}^{-1}$ for flocculated material. These results showed the fact of the adsorbent material is flocs form did not have influence on the adsorption capacity agreeing with others authors ${ }^{6,8,9,18}$ that studied adsorption onto polymeric flocs.

Adsorption studies of isopropilxanthate ions onto $\mathrm{Cu}-\mathrm{FZ}$ as flocculated and powdered forms, in value $\mathrm{pH} 8.0$, show significant results with equilibrium data adjust in the Langmuir model (Figures 11 and 12).

Data of the Figure 11 show value of Langmuir parameter $q_{m}$ of 0.35 meq. $\mathrm{g}^{-1}$ for powdered material and 0.93 meq. $\mathrm{g}^{-1}$ for flocs indicating a high influence of the flocculant polymer on the medium, probably, related with interactions between the polymeric chains of the flocculant and the carbonic chains of isopropilxanthate ions.

\subsection{Reuse of saturated zeolite}

Reuse studies showed high potential for sequential uptakes of barium and sulphate ions from aqueous solutions using saturated zeolite with sulphate ions $\left(\mathrm{SO}_{4} \mathrm{Ba}-\mathrm{Z}\right)$. Thus the $\mathrm{SO}_{4} \mathrm{Ba}-\mathrm{Z}$ uptake barium ions again and this material $\left(\mathrm{BaSO}_{4}-\mathrm{Ba}-\mathrm{RZ}\right)$ showed a high capacity of sulphate ions adsorption constituting a new adsorbent material possible of reuse.

Figures 13 and 14 show equilibrium data (isotherm) of sulphate ions adsorption onto reused zeolite with barium ions as powdered and flocculated forms.

Data of Figure 13 and 14 shows a $\mathrm{q}_{\mathrm{m}} 1.15$ meq.g $\mathrm{g}^{-1}$ for powdered and flocculated materials. These results demonstrate the viability for reuse of the saturated materials, mainly by possibility of sequential

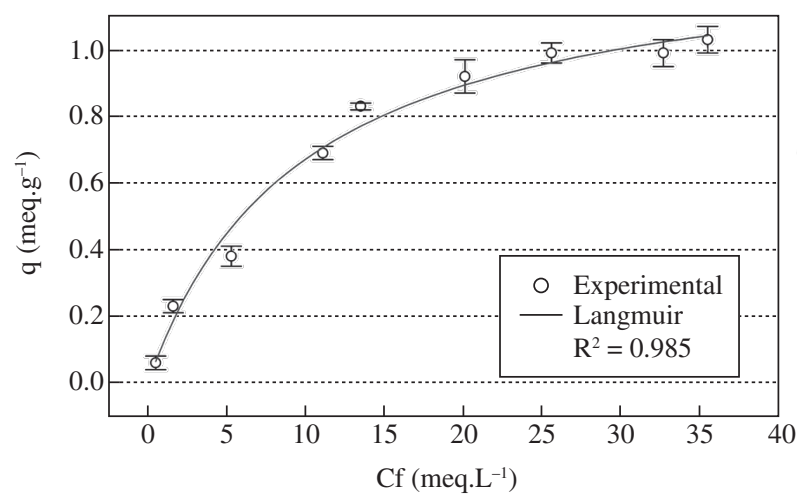

Figure 9. Equilibrium data (isotherm) of sulphate ions uptake, from aqueous solutions, by powdered modified zeolites. Contact time: 2 hours, Ba-Z: 10 g.L. ${ }^{-1}$, temperature: $25^{\circ} \mathrm{C}, \mathrm{pH} 6.0$.

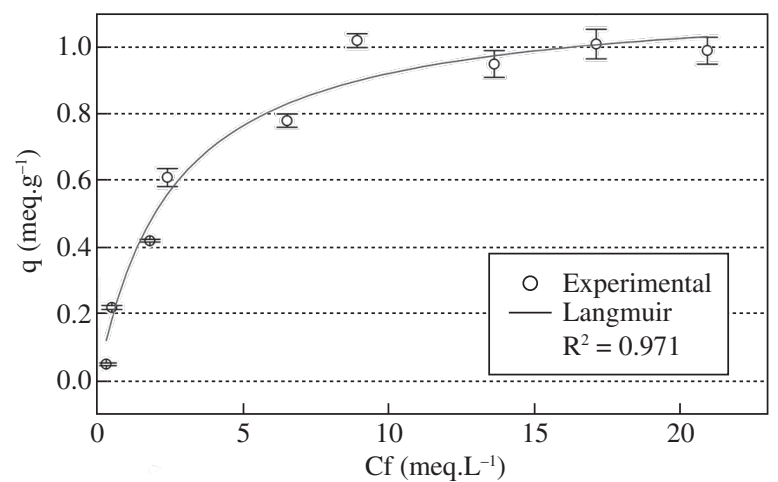

Figure 10. Equilibrium data (isotherm) of sulphate ions uptake, from aqueous solutions, by flocculated modified zeolites. Contact time: 2 hours, Ba-Z: 10 g.L $\mathrm{L}^{-1}$, temperature: $25^{\circ} \mathrm{C}, \mathrm{pH}: 6.0$. 


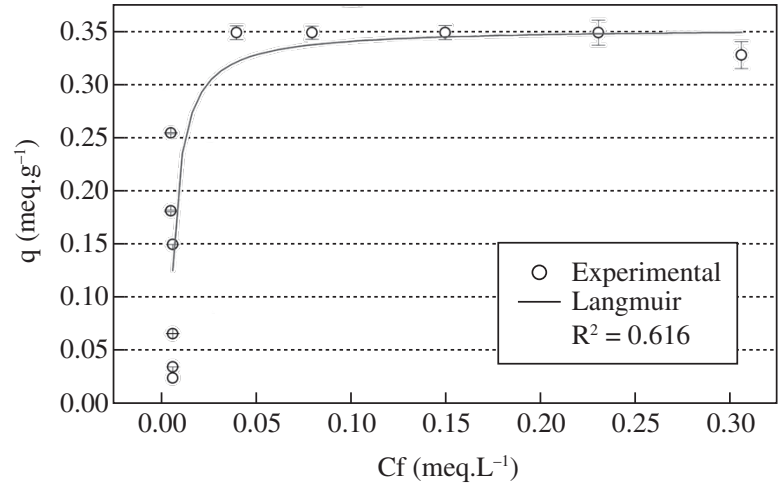

Figure 11. Equilibrium data (isotherm) of isopropilxanthate ions uptake, from aqueous solutions, by powdered modified zeolites. Contact time: 2 hours, $\mathrm{CuZ}$ 10 g.L $\mathrm{L}^{-1}$, temperature: $25^{\circ} \mathrm{C}, \mathrm{pH}:$ 8.0. Experimental error: $\pm 0,004$ meq.g ${ }^{-1}$.

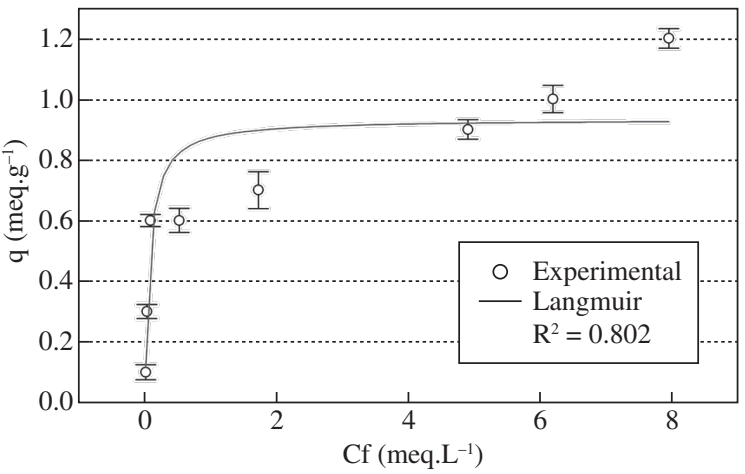

Figure 12. Equilibrium data (isotherm) of isopropilxanthate ions uptake, from aqueous solutions, by flocculated modified zeolites. Contact time: 2 hours, Cu-Z: 10 g.L $\mathrm{L}^{-1}$, temperature: $25^{\circ} \mathrm{C}, \mathrm{pH}: 8.0$. Experimental error: \pm 0.05 meq. $\mathrm{g}^{-1}$.

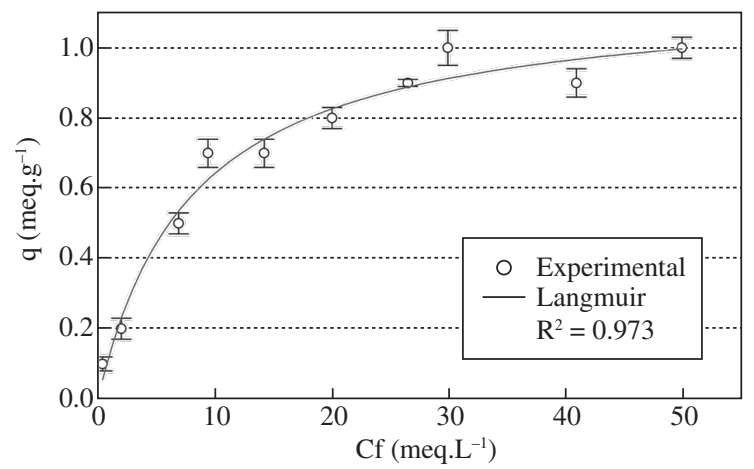

Figure 13. Reuse of powdered saturated zeolite. Equilibrium data (isotherm) for the sulphate ions uptake by $\mathrm{BaSO}_{4}-\mathrm{Ba}-\mathrm{Z}$. Contact time: 2 hours, $\mathrm{Ba}-\mathrm{RZ}$ : 10 g. $\mathrm{L}^{-1}$, temperature, $25^{\circ} \mathrm{C}, \mathrm{pH}: 6.0$.

adsorption of barium and sulphate ions with decrease of cost and absence of new waste production.

Furthermore, all residual solutions (resulted after adsorption) did not have significant either barium or copper ions concentration revealing the absence of desorption (ion exchange) from the surface of the zeolite. Other observation was the colour modification of the zeolite after adsorption of isopropylxanthate ions, confirming a reaction onto or into the particles, resembling the colour of the copper xanthate salt. Harris ${ }^{12}$ reported that the name "xanthate" derived of the Greek word xanthos, which means "yellow" (adapted from the coloration of the insoluble salt of cuprous xanthate).

The Table 4 shows main results obtained in the present work.

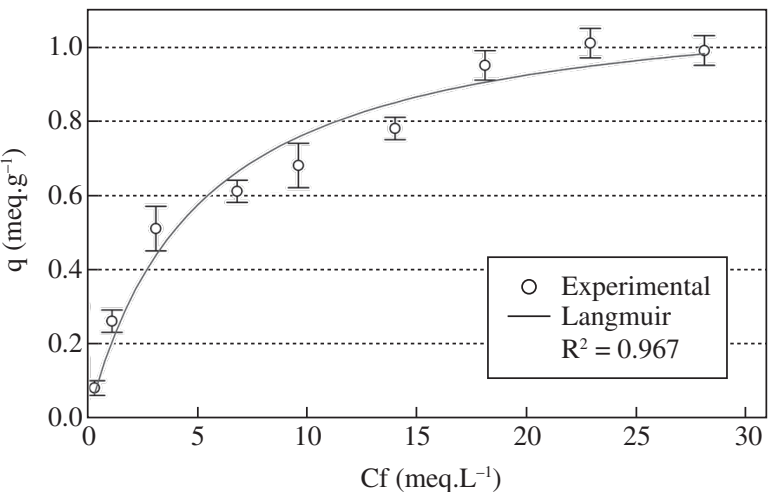

Figure 14. Reuse of flocculated (and saturated) zeolites. Equilibrium data (isotherm) for the sulphate ions uptake from aqueous solutions. Contact time: 2 hours, Ba-RFZ-Ba: 10 g.L $\mathrm{L}^{-1}$, temperature: $25^{\circ} \mathrm{C}$, pH: 6.0 .

Table 4. Summary of results - sulphate and isopropilxanthate removal studies.

\begin{tabular}{lcc}
\hline Pollutant & Adsorbent material & $\mathrm{q}_{\mathrm{m}}\left(\mathrm{meq} \cdot \mathrm{g}^{-1}\right)$ \\
\hline Sulphate ions & FZ-Ba & 1.35 \\
& RFR-Ba & 1.15 \\
& FFZ-Ba & 1.15 \\
& RFFZ-Ba & 1.15 \\
\hline Isopropylxanthate ions & FZ-Cu & 0.35 \\
& FFZ-Cu & 0.97 \\
\hline
\end{tabular}

\section{Conclusions}

Natural zeolites from Chile have, in its crystalline structure mineralogical phase, clinoptilolite, gismondine, heulandite, offretite, quartz and calcium aluminosilicate. Zeolite samples show a mean particle diameter of $25.4 \mu \mathrm{m}$ and the value for specific surface area, cation-exchange capacity, specific mass, porosity and moisture were of $80 \mathrm{~m}^{2} . \mathrm{g}^{-1}, 1.08 \mathrm{meq} \mathrm{NH}_{4}^{+} \mathrm{g}^{-1}, 2.2 \mathrm{~g} \mathrm{~cm}^{-3}, 0.89$ and $2.5 \%$. Zeolite modification involved two stages of ion-exchange: an initial (activation) of the adsorbent material with sodium ions (Na-Z) and other of functionalisation with barium and copper ions (Ba-FZ and $\mathrm{Cu}-\mathrm{FZ}$ ). The latter promoted the application of the zeolite on adsorption processes through chemisorption mechanisms that apart from copper and barium ions uptakes, showed high adsorption of sulphate and isopropilxanthate ions for flocculated $\left(\mathrm{q}_{\text {sulphate }}: 1.15 \mathrm{meq} \cdot \mathrm{g}^{-1}\right.$ and $\mathrm{q}_{\text {xanthate }}: 0.93$ meq. $\left.\mathrm{g}^{-1}\right)$ and as powdered form $\left(\mathrm{q}_{\text {sulphate }}: 1.35 \mathrm{meq} \cdot \mathrm{g}^{-1}\right.$ and $\mathrm{q}_{\mathrm{xanthate}}: 0.35$ meq. $\left.\mathrm{g}^{-1}\right)$. Yet, the reuse of the saturated zeolite, as flocculated and powdered forms, shows viability as a new adsorbent of sulphate ions (both, 1.15 meq. $\mathrm{g}^{-1}$ ). Activated and functionalised zeolites, as powdered or flocculated forms, show new alternatives in the adsorption area and the exhausted zeolites can be reused as saturated adsorbents.

\section{Acknowledgments}

Authors thank all colleagues for the friendly atmosphere at the LTM-Universidade Federal do Rio Grande do Sul, and to all Institutions supporting research in Brazil (FAPERGS, CAPES, CNPq and UFRGS). More, the authors thank the Minera Formas ${ }^{\mathrm{TM}}$ for the zeolites sample.

\section{References}

1. American Public Health Association. Standard methods for the examination of water and wastewater. 19 ed. Washington; 1995. 
2. Cooney DO. Adsorption design for wastewater treatment. Boca Raton: Lewis; 1999.

3. Curkovic L, Cerjan-Stefanovic S, Filipan T. Metal ion exchange by natural and modified zeolites. Water Research. 1996; 31(6):1379-1382.

4. Da Luz BA. Zeólitas: Propriedades e usos industriais. Centro de Tecnologia Mineral. Rio de Janeiro; 1997. p. 68.

5. Dekker M. In: Keishi Goton, Hiroaki Masuda and Ko Higashitani, editor. Powder technology handbook. 2 ed. New York; 1997.

6. De León ABT. Modificação estrutural de bentonitas nacionais modificadas: Caracterização e estudos de adsorção. Porto Alegre: Universidade Federal do Rio Grande do Sul; 2002.

7. Dentel KS, Jamrah IA, Sparks LD. Sorption and cosorption of 1,2,3trichlorobenzene and tannic acid by organo-clays. Water Research. 1998; 32(12):3689-3697.

8. Englert HA. Adsorção em flocos de materiais adsorventes pulverizados e uso em reator de leito expandido/fluidizado. Porto Alegre: Universidade Federal do Rio Grande do Sul; 2004.

9. Englert HA, Santos CC, Gobbi AS., Rubio J. Adsorbing flocs in expanded/ fluidised bed reactors: A new basis for pollutante removal. Minerals Engineering. 2006; 19(9):918-924.

10. Faghihian H, Bowman SR. Adsorption of chromate by clinoptilolite exchanged with various metal cations. Water Research. 2005; 39(6):1099-1104.

11. Haggerty MG., Bowman SR. Sorption of chromate and other inorganic anions by organo-zeolite. Environmental Science and Technology. 1994; 28(3):452-458.

12. Harris HG. Xanthates. Encyclopedia of Chemical Tecnology. 1984; 24(11).

13. Inglezakis LV, Loizidou MD, Grigoropoulou H. Pretreatment of clinoptilolite in ion exchange packed beds. In: $7^{\text {th }}$ International Conference on Environmental Science and Technology; 2001 Sep; Greece.
14. Inglezakis LV, Grigoropoulou H. Effects of operating conditions on the removal of heavy metals by zeolite in fixed bed reactors. Journal of Hazardous Materials. 2004; B112:37-43.

15. Kesraoui-Ouki S, Cheeseman RC, Perry R. Natural zeolite utilization in pollution controls: A review of applications to metals effluents. Journal of Chemical Technology and Biotechnology. 1994; 59(2):121-126.

16. Luna JF. Modificação de Zeólitas para Uso em Catálise. Química Nova. 2001; 24(6):885-892.

17. Milosevic S, Tomasevic-Canovic, M. Modification of the surface of minerals for development the materials-adsorbents. In: $36^{\text {th }}$ International October Conference on Mining and Metallurgy; 2004 Sep 2, October, Bor, Serbia and Montenegro; 2004.

18. Semmens JM, Martin PW. The influence of pretreatment on the capacity and selectivity of clinoptilolite for metal ions. Water Research. 1988; 22(5):537-542.

19. Serpa AL. Adsorção de fenol e de azul de metileno em flocos de carvão ativado pulverizado. Porto Alegre: Universidade Federal do Rio Grande do Sul; 2000.

20. Van Den Hul HJ, Lyklema J. Determination of specific surface areas of dispersed materials, Comparison of the negative adsorption methods with some other methods. Journal of the American Chemical Society. 1968; 90(12):3010-3015.

21. Vujakovic DA, Tomasevic-Canovic RM, Dakovic SA, Dondur TV. The adsorption of sulphate, hydrogenchromate and dihydrogenphosphate anions on surfactant-modified clinoptilolite. Applied Clay Science. 2000; 17(5-6):265-277.

22. Weber WJ, Mcginley JPM, Katz LE. The nature and effects of sorption process in subsurface systems. Transport Processes in Porous Media. Kluwer Academic Publisher. 1991, p. 541-582; Dordrecht.

23. Woodcock TJ, Jones HM. Ultraviolet spectrometry of flotation reagents whith special reference to the determination of xanthate in flotation liquors. Lybrary of Congress Catalog; 1973. Institution of Mining and Metallurgy; 1973; Port Melbourne, Victoria, Australia. 73, p. 88-378. 